\title{
Amycolatopsis jejuensis sp. nov. and Amycolatopsis halotolerans sp. nov., novel actinomycetes isolated from a natural cave
}

\author{
Soon Dong Lee
}

Correspondence

Soon Dong Lee

sdlee@cheju.ac.kr
Department of Science Education, Cheju National University, Jeju 690-756, Republic of Korea

Two actinomycete strains, designated $\mathrm{N} 7-3^{\top}$ and $\mathrm{N} 4-6^{\top}$, were isolated from a natural cave on Jeju Island, Republic of Korea, by using a dilution method, and were subjected to physiological, chemical and molecular characterization. The nearly complete sequences of the 16S rRNA gene were aligned and compared with those of representatives of the genus Amycolatopsis. Phylogenetic analysis showed that the organisms belong to the family Pseudonocardiaceae and formed two distinct lineages within the evolutionary radius of the genus Amycolatopsis. The chemotaxonomic and morphological properties support their classification in the genus Amycolatopsis. The $16 \mathrm{~S}$ rRNA gene sequence data revealed that the closest relatives of strains N7-3 ${ }^{\top}$ and N4- $6^{\top}$ were Amycolatopsis sulphurea ( $97.9 \%$ similarity) and Amycolatopsis albidoflavus (98.7\% similarity), respectively. The combination of physiological and genetic data supported the observation that the organisms could be distinguished from each other and from established species of the genus Amycolatopsis. The names Amycolatopsis jejuensis sp. nov. and Amycolatopsis halotolerans sp. nov. are proposed for the two novel species, with N7-3 ${ }^{\top}\left(=\right.$ NRRL B $\left.-24427^{\top}=J C M 13280^{\top}\right)$ and $\mathrm{N} 4-6^{\top}\left(=\mathrm{NRRL} B-24428^{\top}=\mathrm{JCM} 13279^{\top}\right)$ as the respective type strains.
During the investigation of the biodiversity of cave bacteria including actinomycetes, strains $\mathrm{N} 7-3^{\mathrm{T}}$ and $\mathrm{N} 4-6^{\mathrm{T}}$ were isolated from two different samples collected inside a natural cave. The aims of the present study were to investigate the phylogenetic position of the cave actinomycete strains based on 16S rRNA gene sequence studies and to unravel the taxonomic status of the isolates by morphological, physiological and chemotaxonomic characterization. It was evident from phenotypic and genotypic data that the organisms could be readily differentiated from each other and from established species of the genus Amycolatopsis.

The samples contained soil and dried bat dung collected from inside a natural cave on Jeju Island, Republic of Korea in October 2002. Serial dilution of sample suspensions were transferred onto starch casein agar $[1 \%$ soluble starch, $0.03 \%$ casein, $0.2 \% \mathrm{KNO}_{3}, 0.2 \% \mathrm{NaCl}, 0.002 \% \mathrm{CaCO}_{3}$, $0.005 \% \mathrm{MgSO}_{4} .7 \mathrm{H}_{2} \mathrm{O}, 0.001 \% \mathrm{FeSO}_{4} .7 \mathrm{H}_{2} \mathrm{O}$ and $1.8 \%$ agar $(\mathrm{pH} \mathrm{7 \cdot 2)]} \mathrm{and} \mathrm{the} \mathrm{agar} \mathrm{plates} \mathrm{were} \mathrm{incubated} \mathrm{for}$ 14 days at $30^{\circ} \mathrm{C}$. The isolates were subcultured on yeast extract/malt extract agar for 7 days at $30^{\circ} \mathrm{C}$ and then maintained as mycelial fragments in $20 \%(\mathrm{v} / \mathrm{v})$ glycerol at $-20^{\circ} \mathrm{C}$ or $-70^{\circ} \mathrm{C}$. Strain $\mathrm{N} 7-3^{\mathrm{T}}$ was recovered from dried bat dung,

Published online ahead of print on 11 November 2005 as DOI 10.1099/ijs.0.63881-0.

The GenBank/EMBL/DDBJ accession numbers for the 16S rRNA gene sequences of strains N4-6 ${ }^{\top}$ and $N 7-3^{\top}$ are DQ.000196 and DQ000200, respectively. whereas strain $\mathrm{N} 4-6^{\mathrm{T}}$ was obtained from a soil sample. The reference strains Amycolatopsis sulphurea IFO $13270^{\mathrm{T}}$ $\left(=\mathrm{IMSNU} 20060^{\mathrm{T}}\right)$ and Amycolatopsis albidoflavus KCTC $9471^{\mathrm{T}}\left(=\right.$ IMSNU $22139^{\mathrm{T}}$ ) were used for comparison.

Cultural and morphological characteristics were observed by using yeast extract/malt extract agar (ISP 2 medium), oatmeal agar (ISP 3 medium) and ISP 4 medium (Shirling \& Gottlieb, 1966). The degree of growth, the colour of mycelium and the presence of diffusible pigments of the organisms were recorded on all tested media after incubation for 14 days at $30^{\circ} \mathrm{C}$. The cell morphology was observed from cultures incubated on oatmeal agar for 14 days at $30^{\circ} \mathrm{C}$ by using a light microscope. For electron microscopy, agar blocks with growth were fixed with $1 \%$ osmium tetroxide, dehydrated through a graded series of ethanol and isoamyl acetate and critical-point-dried. Gold-coated specimens were observed using a Hitachi S-2460 scanning electron microscope. The organisms showed morphological properties typical for members of the genus Amycolatopsis in that they produced well-developed, branched aerial and vegetative hyphae, which fragmented into rod-shaped elements. The isolates showed good growth and similar colour patterns of mycelia on all tested agar media. The aerial and vegetative mycelia of strain $\mathrm{N} 7-3^{\mathrm{T}}$ were white and yellowish brown, respectively, whereas strain N4-6 ${ }^{\mathrm{T}}$ produced greyish white-coloured aerial mycelium and brown-coloured substrate mycelium. Neither of the isolates produced diffusible pigments. 
Genomic DNA was extracted and purified using the Wizard Genomic DNA Purification kit (Promega) following the manufacturer's instructions. Cloning of the 16S rRNA gene following PCR-mediated amplification from genomic DNA was carried out as previously described (Lee et al., 2000a). The cloned 16S rRNA gene was sequenced using an ABI Prism BigDye Terminator cycle sequencing kit (Applied Biosystems) and an automatic DNA sequencer (model 3730xl; Applied Biosystems). The sequences determined in this study and reference sequences of the genus Amycolatopsis were aligned by using the CLUSTAL X program (Thompson et al., 1997) and the alignment was manually optimized by comparison with the secondary structure of the Escherichia coli sequence (Brosius et al., 1978). Phylogenetic trees were reconstructed using the least-squares (Fitch \& Margoliash, 1967), maximum-parsimony (Fitch, 1971) and neighbour-joining (Saitou \& Nei, 1987) methods. Evolutionary distances for the least-squares and neighbourjoining methods were computed by a method described by
Jukes \& Cantor (1969). All of the phylogenetic analyses were performed using the programs contained in the PHYLIP package (Felsenstein, 1993). Pseudonocardia thermophila IMSNU $20112^{\mathrm{T}}$ (AJ252830) was used as an outgroup taxon. The reliability of tree topology was evaluated by bootstrap analysis (Felsenstein, 1985) of the neighbour-joining data, using 1000 resamplings. The almost complete 16S rRNA gene sequences for strains $\mathrm{N} 7-3^{\mathrm{T}}$ and $\mathrm{N} 4-6^{\mathrm{T}}$ contained continuous stretches of 1514 and $1512 \mathrm{nt}$, respectively. A total of 1354 unambiguous aligned positions present in all strains between positions 72 and 1452 (E. coli numbering) were used for tree construction. A phylogenetic tree (Fig. 1), constructed from neighbour-joining data, showed that the organisms belong to the family Pseudonocardiaceae (Embley et al., 1988) and form two distinct clades within the evolutionary radius of the genus Amycolatopsis. The other two tree-making algorithms (least-squares and maximumparsimony methods) resulted in trees showing similar topologies (data not shown). Strain $\mathrm{N} 7-3^{\mathrm{T}}$ was closely

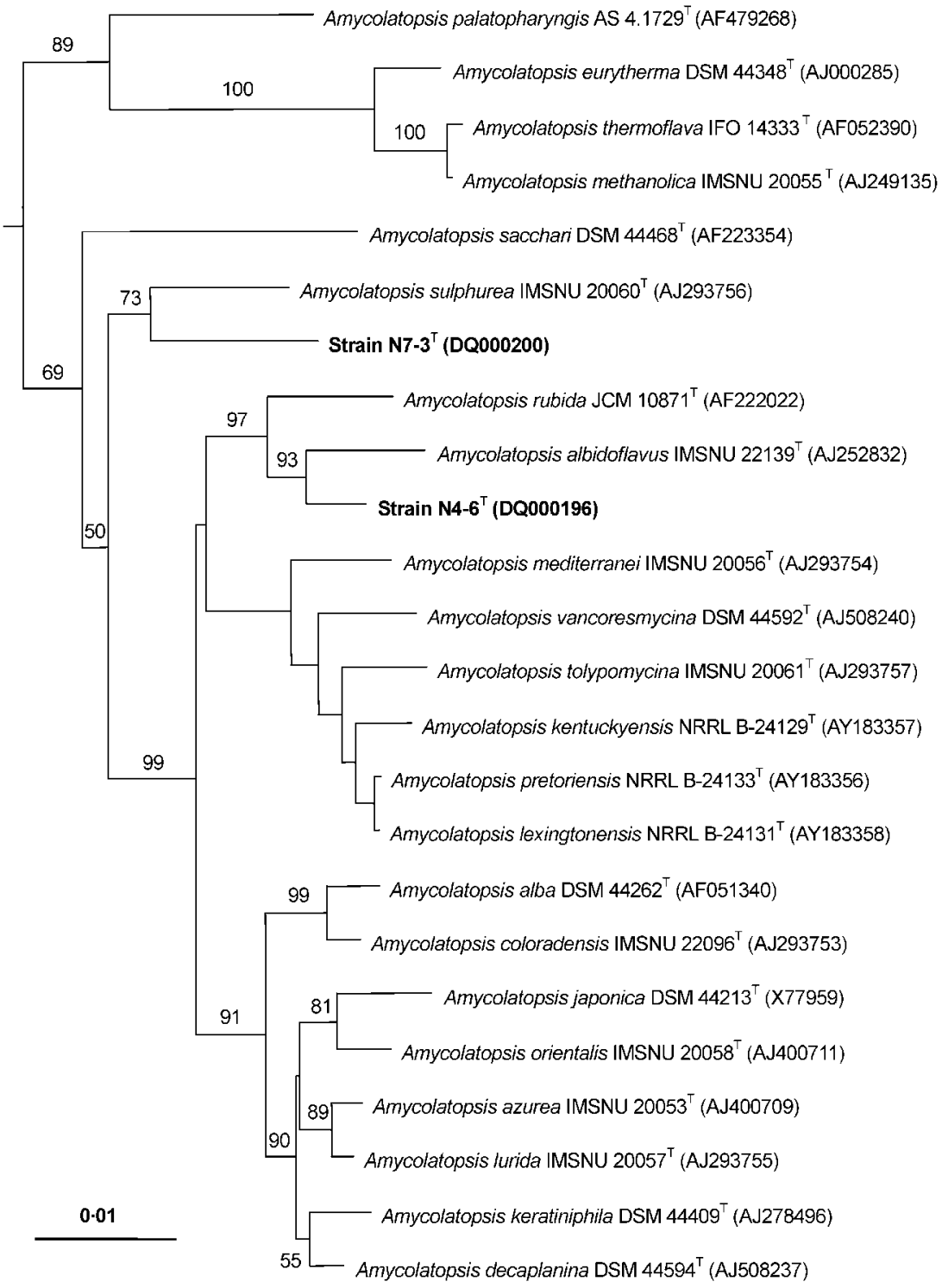

Fig. 1. Neighbour-joining tree based on $16 \mathrm{~S}$ rRNA gene sequences (positions 72-1452, E. coli equivalent) showing the phylogenetic relationships of the cave isolates within the evolutionary radius of the genus Amycolatopsis. Tree was constructed from Juke-Cantor distances by using the neighbour-joining method. Numbers at branching nodes are percentages of occurrence in 1000 bootstrapped trees (only values greater than $50 \%$ are indicated). Outgroup sequence used for analysis was from Pseudonocardia thermophila (not shown). Bar, 1 nt substitution per 100 nt. 
related to A. sulphurea (97.9\% sequence similarity), with high bootstrap support $(73 \%)$. Sequence similarity values with less closely related members of the genus ranged from $94 \cdot 3$ to $97 \cdot 0 \%$. The phylogenetic neighbours of strain N4-6 ${ }^{\mathrm{T}}$ were A. albidoflavus $(98 \cdot 7 \%$ sequence similarity) and $A$. rubida $(98.5 \%$ sequence similarity), again with high bootstrap support ( $93 \%)$.

For chemotaxonomic characterization, the test strains were cultivated in trypticase soy broth (Difco) for 3 days at $30^{\circ} \mathrm{C}$ with shaking. The following properties were determined as described: the isomer of diaminopimelic acid (Staneck \& Roberts, 1974), the acyl type of cell wall (Uchida \& Aida, 1984), the sugar composition of whole-cell walls (Saddler et al., 1991), respiratory menaquinone (Kroppenstedt, 1985), mycolic acid (Minnikin et al., 1980), phospholipid composition (Minnikin et al., 1977) and the G + C content of DNA (Mesbah et al., 1989). Cellular fatty acid methyl esters were prepared by a method described previously (Minnikin, 1988) and analysed by gas chromatography with an Agilent model 6850 gas chromatograph as previously described (Lee et al., 2000b). Most of the chemotaxonomic properties given in the species description were consistent with those of members of the genus Amycolatopsis (Lechevalier et al., 1986; Henssen et al., 1987; Yassin et al., 1993), indicating that chemotaxonomic data also supported the phylogenetic clustering based on 16S rRNA gene sequence studies. The fatty-acid profile contained a mixture of saturated and branched-chain acids, including the major components hexadecanoic acid $\left(\mathrm{C}_{16: 0}\right)$, octadecanoic acid $\left(\mathrm{C}_{18: 0}\right)$, iso-hexadecanoic acid $\left(\mathrm{i}-\mathrm{C}_{16: 0}\right)$ and iso-pentadecanoic acid $\left(\mathrm{i}-\mathrm{C}_{15: 0}\right)$; with an additional hexadecanoic acid $\left(\mathrm{C}_{16: 0}\right)$ in strain N4-6 ${ }^{\mathrm{T}}$ (Table 1). A branched, hydroxy fatty acid was also detected in extracts of the isolates and in A. albidoflavus IMSNU $22139^{\mathrm{T}}$. Strain N7-3 $3^{\mathrm{T}}$ differs from its phylogenetic neighbour, A. sulphurea IMSNU $20060^{\mathrm{T}}$, in that the fatty-acid profile contained minor amounts of $\mathrm{C}_{14: 0}$, $\mathrm{C}_{15: 0}, \mathrm{C}_{20: 0}, \mathrm{C}_{16: 1}$, ai- $\mathrm{C}_{15: 0}$ and 2-OH $\mathrm{C}_{14: 0}$ but not $\mathrm{C}_{17: 1}$, $\mathrm{i}_{-} \mathrm{C}_{17: 1}, \mathrm{i}-\mathrm{C}_{18: 0}, \mathrm{i}_{-} \mathrm{C}_{18: 1}$, or $\mathrm{i}-\mathrm{C}_{18: 0}$ acids. Strain N4-6 ${ }^{\mathrm{T}}$ was readily differentiated from its closest relative, A. albidoflavus IMSNU $22139^{\mathrm{T}}$, in the presence or absence of anteisobranched and unsaturated fatty acids.

Results of the physiological characterization are given in the species description. Catalase activity was determined with a $3 \%(\mathrm{v} / \mathrm{v})$ solution of hydrogen peroxide. The production of hydrogen sulfide was detected in trypticase soy broth by using lead acetate strips. Urease activity was determined by a colour change in Bacto urea broth (Difco). Nitrate reduction and hydrolysis of casein, gelatin and starch were examined by using methods described previously (MacFaddin, 1980). Decomposition of adenine, hypoxanthine, DL-tyrosine and xanthine was examined using a method described by Gordon et al. (1974). The temperature range for growth was tested between 10 and $45^{\circ} \mathrm{C} . \mathrm{NaCl}$ tolerance was determined at final concentrations of 2, 3, 5, 7 and $10 \%(\mathrm{w} / \mathrm{v})$. Acid production from carbohydrates and alcohols was determined by using Bacto OF (oxidation/
Table 1. Fatty-acid composition of the isolates and their phylogenetic neighbours

Strains: 1, Amycolatopsis jejuensis sp. nov. N7-3 ${ }^{\mathrm{T}} ; 2$, Amycolatopsis halotolerans sp. nov. N4-6 ${ }^{\mathrm{T}}$; 3, Amycolatopsis sulphurea IMSNU $20060^{\mathrm{T}} ; 4$, Amycolatopsis albidoflavus IMSNU $22139^{\mathrm{T}}$. Values are percentages of total fatty acids. -, Not detected.

\begin{tabular}{|c|c|c|c|c|}
\hline Fatty acid & 1 & 2 & 3 & 4 \\
\hline \multicolumn{5}{|l|}{ Saturated } \\
\hline $\mathrm{C}_{14: 0}$ & $1 \cdot 2$ & - & - & $1 \cdot 1$ \\
\hline $\mathrm{C}_{15: 0}$ & $2 \cdot 6$ & $3 \cdot 7$ & - & $5 \cdot 8$ \\
\hline$C_{16: 0}$ & $20 \cdot 2$ & $16 \cdot 2$ & $8 \cdot 8$ & $10 \cdot 2$ \\
\hline $\mathrm{C}_{17: 0}$ & $4 \cdot 8$ & $14 \cdot 5$ & $7 \cdot 5$ & $7 \cdot 8$ \\
\hline $\mathrm{C}_{18: 0}$ & $17 \cdot 5$ & $13 \cdot 2$ & $6 \cdot 1$ & $6 \cdot 2$ \\
\hline $\mathrm{C}_{20: 0}$ & $1 \cdot 1$ & - & - & - \\
\hline \multicolumn{5}{|l|}{ Unsaturated } \\
\hline $\mathrm{C}_{15: 1}$ & - & - & - & $2 \cdot 3$ \\
\hline$C_{16: 1}$ & $0 \cdot 9$ & - & - & $4 \cdot 0$ \\
\hline $\mathrm{C}_{17: 1}$ & - & - & $1 \cdot 4$ & $4 \cdot 4$ \\
\hline \multicolumn{5}{|l|}{ Branched } \\
\hline $\mathrm{i}-\mathrm{C}_{14: 0}$ & $2 \cdot 2$ & $4 \cdot 4$ & $1 \cdot 8$ & $9 \cdot 8$ \\
\hline $\mathrm{i}-\mathrm{C}_{15: 0}$ & $14 \cdot 3$ & $13 \cdot 0$ & $11 \cdot 2$ & $8 \cdot 7$ \\
\hline $\mathrm{i}-\mathrm{C}_{16: 0}$ & $14 \cdot 6$ & $17 \cdot 6$ & $19 \cdot 4$ & $26 \cdot 1$ \\
\hline $\mathrm{i}-\mathrm{C}_{17: 1}$ & - & - & $1 \cdot 7$ & - \\
\hline $\mathrm{i}-\mathrm{C}_{17: 0}$ & $5 \cdot 0$ & $5 \cdot 0$ & $5 \cdot 3$ & $1 \cdot 6$ \\
\hline $\mathrm{i}-\mathrm{C}_{18: 1}$ & - & - & $7 \cdot 4$ & - \\
\hline $\mathrm{i}-\mathrm{C}_{18: 0}$ & - & - & $1 \cdot 0$ & - \\
\hline ai- $C_{15: 0}$ & $3 \cdot 2$ & $3 \cdot 2$ & - & - \\
\hline ai- $C_{17: 0}$ & $3 \cdot 5$ & $3 \cdot 1$ & $17 \cdot 7$ & - \\
\hline \multicolumn{5}{|l|}{ Hydroxylated } \\
\hline $2-\mathrm{OH} \mathrm{C} \mathrm{C}_{14: 0}$ & $0 \cdot 6$ & $0 \cdot 8$ & - & - \\
\hline $3-\mathrm{OH}$ i- $\mathrm{C}_{15: 0}$ & $7 \cdot 6$ & $5 \cdot 2$ & - & $7 \cdot 8$ \\
\hline
\end{tabular}

Table 2. Phenotypic characteristics of the isolates and their phylogenetic neighbours

Strains: 1 , A. jejuensis sp. nov. $\mathrm{N} 7-3^{\mathrm{T}} ; 2$, A. halotolerans sp. nov. N4-6 $6^{\mathrm{T}} ; 3$, A. sulphurea IMSNU $20060^{\mathrm{T}} ; 4$, A. albidoflavus IMSNU $22139^{\mathrm{T}}$. + , Positive; - , negative.

\begin{tabular}{|lcccc|}
\hline Characteristic & $\mathbf{1}$ & $\mathbf{2}$ & $\mathbf{3}$ & $\mathbf{4}$ \\
\hline Acid formed from: & & & & \\
$\quad$ Adonitol & + & + & - & + \\
D-Cellobiose & - & + & - & + \\
meso-Erythritol & - & - & - & + \\
D-Lactose & - & - & - & + \\
D-Mannitol & + & + & + & - \\
Melibiose & - & + & - & - \\
D-Trehalose & - & - & + & + \\
D-Xylose & - & - & - & + \\
Decomposition of: & & & & \\
$\quad$ Hypoxanthine & + & + & - & + \\
$\quad$ Xanthine & - & + & - & + \\
Hydrolysis of starch & - & - & + & + \\
Growth at $37^{\circ} \mathrm{C}$ & - & + & + & + \\
Growth in $7 \% \mathrm{NaCl}$ & - & + & - & + \\
\hline
\end{tabular}


fermentation) basal medium (Difco), including each filter-sterilized compound at a final concentration of $1 \%$ $(w / v)$. The isolates can be readily differentiated from each other and from their phylogenetic neighbours by using a range of phenotypic properties (Table 2).

The phenotypic and genotypic data supported the observation that the cave actinomycetes could be classified in two novel species of the genus Amycolatopsis, for which the names Amycolatopsis jejuensis sp. nov. and Amycolatopsis halotolerans sp. nov. are proposed, with N7-3 ${ }^{\mathrm{T}}(=\mathrm{NRRL}$ B- $\left.24427^{\mathrm{T}}=\mathrm{JCM} 13280^{\mathrm{T}}\right)$ and N4-6 ${ }^{\mathrm{T}}\left(=\right.$ NRRL B-24428 ${ }^{\mathrm{T}}=$ JCM $\left.13279^{\mathrm{T}}\right)$ as the respective type strains.

\section{Description of Amycolatopsis jejuensis sp. nov.}

Amycolatopsis jejuensis (je.ju.en'sis. N.L. fem. adj. jejuensis of Jeju Island, Republic of Korea).

Forms well-developed, branched aerial and substrate mycelium that fragment into rod-shaped elements. The aerial mycelium is white and the vegetative mycelium is yellowish brown (ISP 2 medium). No diffusible pigment is produced. Aerobic, Gram-positive, non-acid-alcohol-fast, catalasepositive. Hydrogen sulfide is produced. Nitrate is reduced to nitrite. Exhibits weak urease activity. Growth occurs between 10 and $30^{\circ} \mathrm{C}$. Casein, gelatin, hypoxanthine and DL-tyrosine are decomposed but starch and xanthine are not decomposed. Growth occurs in the presence of $2 \% \mathrm{NaCl}$ but not in $3 \% \mathrm{NaCl}$. Acid is produced from D-arabinose, D-fructose, D-galactose, D-mannose, sucrose, adonitol, myoinositol and D-mannitol. No acid production is observed from L-arabinose, D-cellobiose, dextran, D-glucose, inulin, D-lactose, maltose, D-melezitose, melibiose, methyl $\alpha$-Dglucoside, methyl $\alpha$-D-mannoside, D-raffinose, L-rhamnose, L-ribose, salicin, L-sorbose, D-trehalose, L-xylose, D-xylose, 2,3-butanediol, dulcitol, meso-erythritol, glycerol, 1,2propanediol, D-sorbitol or D-xylitol. Type IV cell wall (meso-diaminopimelic acid, arabinose and galactose). The acyl type of muramic acid is acetyl type. Predominant menaquinone is MK-9 $\left(\mathrm{H}_{4}\right)$. Phospholipid profile contains diphosphatidylglycerol, phosphatidylethanolamine, phosphatidylglycerol, phosphatidylinositol and phosphatidylinositol mannoside. Mycolic acids are not present. Predominant fatty acids are $\mathrm{C}_{16: 0}(20 \cdot 2 \%), \mathrm{C}_{18: 0}(17 \cdot 5 \%)$, $\mathrm{i}-\mathrm{C}_{16: 0}(14 \cdot 6 \%)$ and $\mathrm{i}-\mathrm{C}_{15: 0}(14 \cdot 3 \%)$. A branched, hydroxy fatty acid ( $\left.3-\mathrm{OH} \mathrm{i}-\mathrm{C}_{15: 0}\right)$ is also detected. The $\mathrm{G}+\mathrm{C}$ content of the DNA is $71 \cdot 7 \mathrm{~mol} \%$.

The type strain, N7- $3^{\mathrm{T}}\left(=\right.$ NRRL B- $\left.24427^{\mathrm{T}}=\mathrm{JCM} 13280^{\mathrm{T}}\right)$, was isolated from dried bat dung inside a natural cave on Jeju Island, Republic of Korea.

\section{Description of Amycolatopsis halotolerans sp. nov.}

Amycolatopsis halotolerans (ha.lo.to'le.rans. Gr. n. hals salt; L. pres. part. tolerans tolerating, enduring; N.L. part. adj. halotolerans salt-tolerating).
Forms well-developed, branched aerial and substrate mycelium that fragment into rod-shaped elements. The aerial mycelium is greyish white and the vegetative mycelium is brown (ISP 2 medium). Aerobic, Gram-positive, non-acidalcohol-fast, catalase-positive. Urease-positive. Hydrogen sulfide is produced. Nitrate is reduced to nitrite. Growth occurs between 10 and $37^{\circ} \mathrm{C}$. Growth does not occur at or above $45^{\circ} \mathrm{C}$. Hypoxanthine, DL-tyrosine and xanthine are decomposed. Casein and gelatin are hydrolysed but starch is not hydrolysed. Growth occurs in the presence of $7 \%$ $\mathrm{NaCl}$ but not in $10 \% \mathrm{NaCl}$. Acid is produced from Dcellobiose, D-fructose, D-galactose, D-mannose, melibiose, L-ribose, sucrose, L-xylose, adonitol, glycerol, myo-inositol and D-mannitol. No acid production is observed from L-arabinose, D-arabinose, dextran, D-glucose, inulin, Dlactose, maltose, D-melezitose, methyl $\alpha$-D-glucoside, methyl $\alpha$-D-mannoside, D-raffinose, L-rhamnose, salicin, L-sorbose, D-trehalose, D-xylose, 2,3-butanediol, dulcitol, meso-erythritol, 1,2-propanediol, D-sorbitol or D-xylitol. Type IV cell wall (meso-diaminopimelic acid, arabinose and galactose). The acyl type of muramic acid is acetyl type. Predominant menaquinone is MK- $9\left(\mathrm{H}_{4}\right)$, with MK-9 $\left(\mathrm{H}_{6}\right)$ and MK-9 $\left(\mathrm{H}_{8}\right)$ as minor components. Phospholipid profile contains phosphatidylethanolamine, diphosphatidylglycerol, phosphatidylglycerol and phosphatidylinositol. Mycolic acids are not present. Predominant fatty acids are $\mathrm{i}-\mathrm{C}_{16: 0}(17 \cdot 6 \%)$, $\mathrm{C}_{16: 0}(16 \cdot 2 \%), \mathrm{C}_{18: 0}(13 \cdot 2 \%)$ and $\mathrm{i}-\mathrm{C}_{15: 0}(13 \cdot 0 \%)$. A considerable amount of a branched, hydroxy fatty acid (3-OH i- $\mathrm{C}_{15: 0}$ ) is also detected. The $\mathrm{G}+\mathrm{C}$ content of the DNA is $72 \cdot 5 \mathrm{~mol} \%$.

The type strain, N4-6 $6^{\mathrm{T}}\left(=\right.$ NRRL B-24428 $\left.{ }^{\mathrm{T}}=\mathrm{JCM} 13279^{\mathrm{T}}\right)$, was isolated from a soil sample inside a natural cave on Jeju Island, Republic of Korea.

\section{Acknowledgements}

This work was supported by Korean Research Foundation Grant (KRF-2003-041-C00316). The author is indebted to H. L. Yang for the analysis of cellular fatty acids.

\section{References}

Brosius, J., Palmer, J. L., Kennedy, J. P. \& Noller, H. F. (1978). Complete nucleotide sequence of a $16 \mathrm{~S}$ ribosomal RNA gene from Escherichia coli. Proc Natl Acad Sci U S A 75, 4801-4480.

Embley, T. M., Smida, J. \& Stackebrandt, E. (1988). The phylogeny of mycolate-less wall chemotype IV actinomycetes and the description of Pseudonocardiaceae fam. nov. Syst Appl Microbiol 11, 44-52.

Felsenstein, J. (1985). Confidence limits on phylogenies: an approach using the bootstrap. Evolution 39, 783-791.

Felsenstein, J. (1993). PHYLIP (phylogenetic inference package), version 3.5. Distributed by the author. Department of Genome Sciences, University of Washington, Seattle, USA.

Fitch, W. M. (1971). Towards defining the course of evolution: minimum change for a specific tree topology. Syst Zool 20, 406-416.

Fitch, W. M. \& Margoliash, E. (1967). Construction of phylogenetic trees: a method based on mutation distances as estimated from 
cytochrome $c$ sequences is of general applicability. Science 155, 279-284.

Gordon, R. E., Barnett, D. A., Handerhan, J. E. \& Pang, C. H.-N. (1974). Nocardia coeliaca, Nocardia autotrophica, and the nocardin strain. Int J Syst Bacteriol 24, 54-63.

Henssen, A., Kothe, H. W. \& Kroppenstedt, R. M. (1987). Transfer of Pseudonocardia azurea and "Pseudonocardia fastidiosa" to the genus Amycolatopsis, with emended species description. Int J Syst Bacteriol 37, 292-295.

Jukes, T. H. \& Cantor, C. R. (1969). Evolution of protein molecules. In Mammalian Protein Metabolism, pp. 21-132. Edited by H. N. Munro. New York: Academic Press.

Kroppenstedt, R. M. (1985). Fatty acid and menaquinone analysis of actinomycetes and related organisms. In Chemical Methods in Bacterial Systematics, pp. 173-199. Edited by M. Goodfellow \& D. E. Minnikin. London: Academic Press.

Lechevalier, M. P., Prauser, H., Labeda, D. P. \& Ruan, J.-S. (1986). Two new genera of nocardioform actinomycetes: Amycolata gen. nov. and Amycolatopsis gen. nov. Int J Syst Bacteriol 36, 29-37.

Lee, S. D., Kim, E. S. \& Hah, Y. C. (2000a). Phylogenetic analysis of the genera Pseudonocardia and Actinobispora based on the $16 \mathrm{~S}$ ribosomal DNA sequences. FEMS Microbiol Lett 182, 125-129.

Lee, S. D., Kim, E. S., Roe, J.-H., Kim, J.-H., Kang, S.-O. \& Hah, Y. C. (2000b). Saccharothrix violacea sp. nov., isolated from a gold mine cave, and Saccharothrix albidocapillata comb. nov. Int J Syst Evol Microbiol 50, 1315-1323.

MacFaddin, J. F. (1980). Biochemical Tests for Identification of Medical Bacteria, 2nd edn. Baltimore: Williams \& Wilkins.

Mesbah, M., Premachandran, U. \& Whitman, W. B. (1989). Precise measurement of the $\mathrm{G}+\mathrm{C}$ content of deoxyribonucleic acid by high-performance liquid chromatography. Int J Syst Bacteriol 39, 159-167.
Minnikin, D. E. M. (1988). Isolation and purification of mycobacterial wall lipids. In Bacterial Cell Surface Techniques, pp. 125-135. Edited by I. C. Hancock \& I. R. Poxton. Chichester: Wiley.

Minnikin, D. E., Alshamaony, L. \& Goodfellow, M. (1977). Differentiation of Mycobacterium, Nocardia, and related taxa by thin layer chromatographic analysis of whole-cell methanolysates. J Gen Microbiol 88, 200-204.

Minnikin, D. E., Hutchinson, I. G., Caldicott, A. B. \& Goodfellow, M. (1980). Thin layer chromatography of methanolysates of mycolic acid-containing bacteria. J Chromatogr 188, 221-233.

Saddler, G. S., Tavecchia, P., Lociuro, S., Zanol, M., Colombo, E. \& Selva, E. (1991). Analysis of madurose and other actinomycete whole cell sugars by gas chromatography. J Microbiol Methods 14, 185-191.

Saitou, N. \& Nei, M. (1987). The neighbor-joining method: a new method for reconstructing phylogenetic trees. Mol Biol Evol 4, 406-425.

Shirling, E. B. \& Gottlieb, D. (1966). Methods for characterization of Streptomyces species. Int J Syst Bacteriol 16, 313-340.

Staneck, J. L. \& Roberts, G. D. (1974). Simplified approach to identification of aerobic actinomycetes by thin-layer chromatography. Appl Microbiol 28, 226-231.

Thompson, J. D., Gibson, T. J., Plewniak, F., Jeanmougin, F. \& Higgins, D. G. (1997). The ClUSTAL $X$ windows interface: flexible strategies for multiple sequence alignment aided by quality analysis tools. Nucleic Acids Res 25, 4876-4882.

Uchida, K. \& Aida, K. (1984). An improved method for the glycolate test for simple identification of the acyl type of bacterial cell walls. J Gen Appl Microbiol 30, 131-134.

Yassin, A. F., Haggenei, B., Budzikiewicz, H. \& Schaal, K. P. (1993). Fatty acid and polar lipid composition of the genus Amycolatopsis: application of fast bombardment-mass spectrometry to the structure analysis of underivatized phospholipids. Int J Syst Bacteriol 43, 414-420. 